\title{
Transduction of Pig Small Airway Epithelial Cells and Distal Lung Progenitor Cells by AAV4
}

\author{
Oliver G. Chen ${ }^{1,+} \oplus$, Steven E. Mather ${ }^{2,+}$, Christian M. Brommel ${ }^{2}$, Bradley A. Hamilton ${ }^{2}$, Annie Ehler ${ }^{2}$, \\ Raul Villacreses ${ }^{2}$, Reda E. Girgis ${ }^{3}$, Mahmoud Abou Alaiwa ${ }^{2}$, David A. Stoltz ${ }^{2,4,5}$, Joseph Zabner ${ }^{2, *}$ \\ and Xiaopeng $\mathrm{Li}^{1, *}$
}

1 Department of Pediatrics \& Human Development, Michigan State University, Grand Rapids, MI 49503, USA; chengua5@msu.edu

2 Department of Internal Medicine, University of Iowa, Iowa City, IA 52242, USA; steven-mather@uiowa.edu (S.E.M.); christian-brommel@uiowa.edu (C.M.B.); bradley5@stanford.edu (B.A.H.); annie.ehler.4@gmail.com (A.E.); raul-villacresesrada@uiowa.edu (R.V.); mahmoud-aboualaiwa@uiowa.edu (M.A.A.); david-stoltz@uiowa.edu (D.A.S.)

3 Pulmonary Medicine, Spectrum Health, Grand Rapids, MI 49503, USA; reda.girgis@spectrumhealth.org

4 Department of Biomedical Engineering, University of Iowa, Iowa City, IA 52242, USA

5 Department of Molecular Physiology and Biophysics, Carver College of Medicine, University of Iowa, Iowa City, IA 52242, USA

* Correspondence: joseph-zabner@uiowa.edu (J.Z.); lixiao@msu.edu (X.L.); Tel.: +1-319-356-4419 (J.Z.); +1-616-234-2847 (X.L.); Fax: +1-319-353-6406 (J.Z.); +1-616-234-2838 (X.L.)

+ These authors contributed equally to this work.

check for updates

Citation: Chen, O.G.; Mather, S.E.; Brommel, C.M.; Hamilton, B.A.; Ehler, A.; Villacreses, R.; Girgis, R.E.; Abou Alaiwa, M.; Stoltz, D.A.; Zabner, J.; et al. Transduction of Pig Small Airway Epithelial Cells and Distal Lung Progenitor Cells by AAV4. Cells 2021, 10, 1014. https://doi.org/ 10.3390/cells10051014

Academic Editor: Michael Gray

Received: 29 March 2021

Accepted: 22 April 2021

Published: 25 April 2021

Publisher's Note: MDPI stays neutral with regard to jurisdictional claims in published maps and institutional affiliations.

Copyright: (c) 2021 by the authors. Licensee MDPI, Basel, Switzerland. This article is an open access article distributed under the terms and conditions of the Creative Commons Attribution (CC BY) license (https:// creativecommons.org/licenses/by/ $4.0 /)$.

\begin{abstract}
Cystic fibrosis (CF) is caused by genetic mutations of the $\mathrm{CF}$ transmembrane conductance regulator (CFTR), leading to disrupted transport of $\mathrm{Cl}^{-}$and bicarbonate and CF lung disease featuring bacterial colonization and chronic infection in conducting airways. CF pigs engineered by mutating CFTR develop lung disease that mimics human CF, and are well-suited for investigating CF lung disease therapeutics. Clinical data suggest small airways play a key role in the early pathogenesis of CF lung disease, but few preclinical studies have focused on small airways. Efficient targeted delivery of CFTR cDNA to small airway epithelium may correct the CFTR defect and prevent lung infections. Adeno-associated virus $4(\mathrm{AAV} 4)$ is a natural AAV serotype and a safe vector with lower immunogenicity than other gene therapy vectors such as adenovirus. Our analysis of AAV natural serotypes using cultured primary pig airway epithelia showed that AAV4 has high tropism for airway epithelia and higher transduction efficiency for small airways compared with large airways. AAV4 mediated the delivery of CFTR, and corrected $\mathrm{Cl}^{-}$transport in cultured primary small airway epithelia from CF pigs. Moreover, AAV4 was superior to all other natural AAV serotypes in transducing ITG $\alpha 6 \beta 4^{+}$pig distal lung progenitor cells. In addition, AAV4 encoding eGFP can infect pig distal lung epithelia in vivo. This study demonstrates AAV4 tropism in small airway progenitor cells, which it efficiently transduces. AAV4 offers a novel tool for mechanistical study of the role of small airway in CF lung pathogenesis in a preclinical large animal model.
\end{abstract}

Keywords: cystic fibrosis 1; CFTR; small airway epithelia; progenitor cells; AAV4

\section{Introduction}

Cystic fibrosis (CF) is caused by genetic mutations of the CF transmembrane conductance regulator (CFTR), leading to disrupted transport of $\mathrm{Cl}^{-}$and bicarbonate [1,2]. CF lung disease manifests as chronic airway infection and inflammation, the leading causes of CF morbidity and mortality. Though CFTR potentiators and correctors have been approved to treat CF patients with certain CFTR defects [3], new therapeutic strategies are still urgently needed for CF patients not responsive to current therapy. The CF pig model, engineered with deletion or mutation of CFTR, develops pathologies that mimic human CF [4], including spontaneous airway infections [4]. We have utilized the CF pig model for 
proof-of-concept gene therapy studies and for understanding the regional differences in airway epithelium $[5,6]$.

Clinical data suggest small airways are of major importance in early CF pathogenesis. For example, histopathological samples from CF infants show bronchiolar dilation, thickening of the wall of small airways, and air trapping in the alveolar space [7-11]. Pulmonary function tests of young people with CF (6-16 years old) show progressive decline in small airway function as measured by Forced Expiratory Flow $\left(\mathrm{FEF}_{25-75 \%}\right)$, whereas large airway function measured by Forced Expiratory Volume in $1 \mathrm{~s}$ (FEV1) remains stable [12]. In older people with CF, compared to older people with Chronic Obstructive Pulmonary Disease (COPD), small airways are nearly 300\% thicker, whereas large airways have only $10 \%$ greater thickness [13]. These data suggest small airways play a key role in the early pathogenesis of CF lung diseases [7-11]. Most laboratory studies of CF lung disease, however, have focused on the larger central airways, rather than the small airways where the disease may initiate. Therefore, potentially druggable targets to prevent CF progression have been overlooked.

Efficient gene therapy can conceptually correct the CFTR defect and prevent lung infections. Several types of viral vectors have been used to transfer functional CFTR genes into the lungs of CF ferrets and CF pigs [14,15]. Recombinant adeno-associated virus (AAV) has emerged as an attractive delivery tool for gene transfer approaches due to its non-pathogenic and less immunogenic safety profile, ability to transduce dividing and non-dividing cells, and tissue and species specificity [16-18]. The efficiency of AAV targeting airway epithelia has significantly improved [19-24] via mutagenesis of AAV capsids [25] and targeted evolution selection of efficient serotypes $[17,26]$. Our group previously reported a targeted evolution selection process in primary cultures of human airway epithelia to yield a novel AAV2.5T. Unfortunately, AAV2.5T does not transduce pig airway epithelia [27]. We applied a novel in vivo evolution strategy to select an AAV capsid (AAV2H22) that efficiently infects pig airway epithelia but does not transduce pig alveolar epithelial cells in vitro [5]. AAV4 is a natural AAV serotype rarely tested for CF gene therapy, as one previous study showed that mucins inhibit AAV4 transduction of cultured human large airway epithelial cells [28]. This is presumably because mucins glycosylated with $\alpha 2-3$ O-linked sialic acids bind to AAV4 and prohibit AAV4 from transfecting epithelial cells [28]. However, after intravenous administration, AAV4 targets the lungs more than other organs in mice [29,30], although the cell types transduced by AAV4 in the lungs are not clear.

For gene therapy to be a viable therapeutic strategy for CF, it is necessary to target the appropriate cell type. Targeting progenitor cells rather than terminally differentiated cells is a strategy to achieve durable transgene expression in the lung. However, discrete populations of epithelial progenitor cells, with distinct differentiation potentials, vary along the proximal to distal axis of the airways [31,32]. We have focused on identifying progenitor cells residing in the distal small airways, where clinical and autopsy observations suggest CF originates. In previous studies, we identified integrin (ITG) $\alpha 6 \beta 4^{+}$cells with multipotent stem/progenitor potential for both small airway and alveolar epithelia in the human and mouse lung $[33,34]$. We term these cells distal lung epithelial progenitors (DLEP). DLEPs have the potential to differentiate into multiple lineages, including $\mathrm{K}^{+}$basal cells, $\mathrm{CC} 10^{+}$ club cells and Muc5 $\mathrm{AC}^{+}$goblet cells in humans and $\mathrm{CC} 10^{+}$club, $\mathrm{SPC}^{+}$type II alveolar, and $\mathrm{T} 1 \alpha^{+}$type I alveolar cells in mice $[33,34]$. Moreover, DLEPs can regenerate the lung in a mouse model of injury [33,34].

Our objective, herein, was to identify AAV vectors that target DLEPs in the pig lung. We selected DLEPs as our initial focus because of our interest in the role of the small airway in the pathogenesis of CF and the cuboidal epithelia of small airway allowing vector access from the apical side, as well as the ability of these cells to proliferate and differentiate into the various lineages of airway and alveolar epithelial cells. Our screen of natural and evolved AAV serotypes revealed extremely high tropism of AAV4 for pig DLEPs. 


\section{Materials and Methods}

\subsection{Animals}

All animal studies were reviewed and approved by the Michigan State University and University of Iowa Animal Care and Use Committee. Non-CF pigs and CF pigs within one week old were obtained from Exemplar Genetics (Exemplar Genetics, Sioux Center, IA, USA) and Michael Fanning Farms (Howe, IN, USA).

\subsection{Isolation of DLEPS}

A schematic workflow for isolation of large, small airway epithelial cells and DLEPs was listed in supplementary Figure S1. First, airways were detached from lung parenchyma by blunt dissection. Then small airways were further separated from large airways by microdissection. Large, small airways cells and distal lung progenitor cells were isolated from different regions of the pig lungs. DLEPs were isolated from the pig distal lung parenchymal tissue using a modified protocol [33]. Briefly, the pulmonary artery was perfused with PBS solution and the distal air spaces were lavaged 10 times with $\mathrm{Ca}^{2+}$-and $\mathrm{Mg}^{2+}$-free PBS solution (0.5 mM EGTA and 0.5 mM EDTA). Piglet lungs were excised and the whole airway tree was micro-dissected by carefully combing off the parenchymal tissue. A trypsin-elastase combination $(0.5 \mathrm{mg} / \mathrm{mL}$ elastase in $0.5 \%$ trypsin solution) was used to enzymatically digest the parenchymal tissue at $37{ }^{\circ} \mathrm{C}$ for $60 \mathrm{~min}$ with shaking. Single-cell suspensions were co-stained with a rat monoclonal $\alpha 6$ antibody (BD Biosciences, San Jose, CA, USA), a mouse monoclonal primary antibody against EPCAM, and an antibody against CD31 followed by secondary antibodies anti-rat Alexa-Fluor 647 and anti-mouse Alexa-Fluor 488 (Invitrogen, Grand Island, NY, USA). Cells were sorted for $\alpha 6^{+} / \mathrm{EPCAM}^{+} / \mathrm{CD}^{-} 1^{-}$expression using the FACSAria III Cell Sorter (BD Biosciences) at the University of Iowa Flow Cytometry Core Facility.

\subsection{Isolation of Large and Small Airway Epithelia}

Piglet lungs were excised and the whole airway tree was micro-dissected by carefully combing off the parenchymal tissue. Subsequently, the vascular tissue was separated from the airway tree by blunted dissection. Proximal large airways, including trachea and main stem bronchi, and distal small airways (diameter $\sim 200 \mu \mathrm{m}$ ) were dissected out separately from the airway tree. In order to isolate enough small airway epithelia for study in vitro, the entire airway tree was micro-dissected. Next, primary porcine airway epithelia were isolated according to an adapted procedure originally developed for tracheal airway cells [35]. Primary epithelial cells were seeded onto collagen-coated, semi-permeable membranes (Corning \#3470) at density of $10^{6}$ cells $/ \mathrm{cm}^{2}$ and cultured at the air-liquid interface at $37^{\circ} \mathrm{C}$ in a $5 \% \mathrm{CO}_{2}$ atmosphere, as previously described [36]. For small airway epithelia, the typical yield per lung was $3-4 \times 10^{6}$ cells. In the first week of seeding at the air-liquid interface, cells were maintained in Small Airway Growth Media (Lonza, Basel, Switzerland) supplemented with $10 \mathrm{ng} / \mathrm{mL}$ keratinocyte growth factor (KGF) for one week, after which cells were maintained in USG media. All experiments were performed $\sim 2$ weeks after seeding on matched large and small airway epithelia isolated from the same animal and cultured under identical conditions.

\subsection{Viral Transduction of Pig Airway Epithelia}

The self-complimentary AAV vectors utilized in this study expressed GFP under the control of a CMV promoter. AAV2 or AAV2H22 derivatives have been previously reported [5]. AAV production was performed as a fee for service at the University of Iowa Viral Vector Core (https: / / medicine.uiowa.edu/vectorcore/, accessed on 20 April 2021). CFTR transgene in AAV4 contains a deleted portion of the R domain (CFTR $\triangle R, 708-759)$, a shortened CMV immediate/early (173CMVie) enhancer/promoter, and minimal poly(A) signal as described by Ostedgaard et al. [37].

For transduction of well-differentiated primary airway epithelia cultured at the airliquid interface (ALI) in vitro, cells were pre-treated treated with $5 \mu \mathrm{M}$ doxorubicin (Cal- 
biochem, La Jolla, CA, USA) for $4 \mathrm{~h}$, which has been shown to effectively increase viral capsid ubiquitination and transduction of recombinant AAV vectors [38]. Next, AAV vectors harboring eGFP $\left(10^{5} \mathrm{vg} /\right.$ cell) were diluted in EMEM and added to the apical surface of pig airway epithelia. Samples were incubated overnight at $37^{\circ} \mathrm{C}$, followed by $5 \mu \mathrm{M}$ Hoechst33342 (\#H1399, Invitrogen, Carlsbad, CA, USA) for 4 h, as previously described [39]. Then, two weeks after AAV transduction, cells were analyzed for eGFP expression.

Freshly isolated pig DLEPs $\left(4 \times 10^{4}\right.$ cells/transwell) were mixed with the AAV serotypes $\left(10^{5} \mathrm{vg} /\right.$ cell) and cultured in $100 \mu \mathrm{L}$ Matrigel/ DMEM (1:1) per transwell. Then, two weeks later, $\mathrm{GFP}^{+}$positive colonies were visualized and counted as previously described [33].

For transduction in vivo, AAV4 > eGFP $\left(1 \times 10^{12} \mathrm{vg} /\right.$ animal $)$ was instilled into the lungs of one-week old non-CF pigs (4-5 kg). After intubating the pigs, a PE50 catheter was used to guide delivery to the left distal lung. The virus was administered in the presence of $250 \mu \mathrm{M}$ doxorubicin in $0.5 \mathrm{~mL}$ solution. Then, two weeks post-infection, animals were euthanized by intracardiac injection of Euthasol and serial sections of the whole airway tree analyzed for GFP expression as described below.

\subsection{Fluorescence Imaging and Immunofluorescence}

For in vitro analysis of GFP expression, cells were fixed with $4 \%$ paraformaldehyde. For in vivo analysis of GFP expression, tissues were fixed with $4 \%$ paraformaldehyde, embedding in O.C.T. compound (Tissue Tek by Sakura Finetek, Torrance, CA, USA), cryosectioned into $7 \mu \mathrm{m}$ sections, and permeabilized in $0.2 \%$ Triton X-100. Nuclei were counterstained with DAPI. GFP-positive cells visualized with an Olympus Fluoview FV1000 confocal microscope with a UPLSAPO $\times 60$ oil lens.

\subsection{Lectin Profiling}

Fluorescein-conjugated lectins were purchased from Vector Laboratories (Burlingame, CA, USA). The lectins were bound to cells on ice for $15 \mathrm{~min}$ at the following concentrations: Concanavalin A (ConA), $1 \mathrm{mg} / \mathrm{mL}$; WGA, $30 \mu \mathrm{g} / \mathrm{mL}$, jacalin, $1 \mathrm{mg} / \mathrm{mL}$; MMA Maakia amurensis lectin I, $100 \mu \mathrm{g} / \mathrm{mL}$. Next, the cells were washed three times with ice-cold phosphate-buffered saline (PBS). The cells were then fixed with $4 \%$ paraformaldehyde in PBS at room temperature for $25 \mathrm{~min}$, followed by another PBS wash. Samples were then visualized using an Olympus IX71 fluorescence microscope.

\subsection{Ussing Studies}

The short-circuit current (Isc) was measured, using a $\mathrm{Cl}^{-}$gradient in modified Ussing chambers (Physiological Instruments) as previously described [6].

\subsection{Statistics}

Data are expressed as mean \pm SEM. For analyses that compared large and small airways from the same animal, we used a non-parametric Wilcoxon signed-rank test. $p$ values are presented in figure legends. All analyses were done using Prism software Version 8.0.

\section{Results}

\subsection{DLEPs Can Be Isolated from Pig Distal Lungs}

We previously developed a method to selectively isolate the different regions of the pig airway: large airways, small airways, and distal parenchyma (Figure S1) [6]. Large airway epithelial cells are isolated from trachea and bronchus. Small airway epithelial cells are isolated from terminal airways with a diameter $<200 \mu \mathrm{m}$ [6]. DLEPs are isolated from the distal parenchyma using $\alpha 6$ ITG, a marker which was previously used for identifying DLEPs in human and mice [33,34]. We immunostained pig small airways and distal parenchyma with antibodies against $\alpha 6$ ITG and demonstrated that, similar to human small airway, antibodies against $\alpha 6$ ITG labeled both $\mathrm{K}^{+}$basal cells and the putative 
$\mathrm{K} 5^{-} \alpha 6 \beta 4^{+}$DLEPs (Figure 1A). We also verified that the antibody, raised against human $\alpha 6$ ITG, could recognize pig $\alpha 6$ ITG (Figure 1B,C) for fluorescence-activated cell sorting (FACS). We next immunostained single cell preparations from enzyme digested small airways and distal lung parenchyma for $\alpha 6$ ITG (progenitor cell marker), EPCAM (epithelial marker) and CD31 (endothelial marker). DLEPs were isolated using FACS to sort for ITG $\alpha 6^{+} / \mathrm{EPCAM}^{+}$(epithelial marker)/CD31- (endothelial marker) cells (Figure 2). These results demonstrated the feasibility of isolating DLEPs from pig lung.
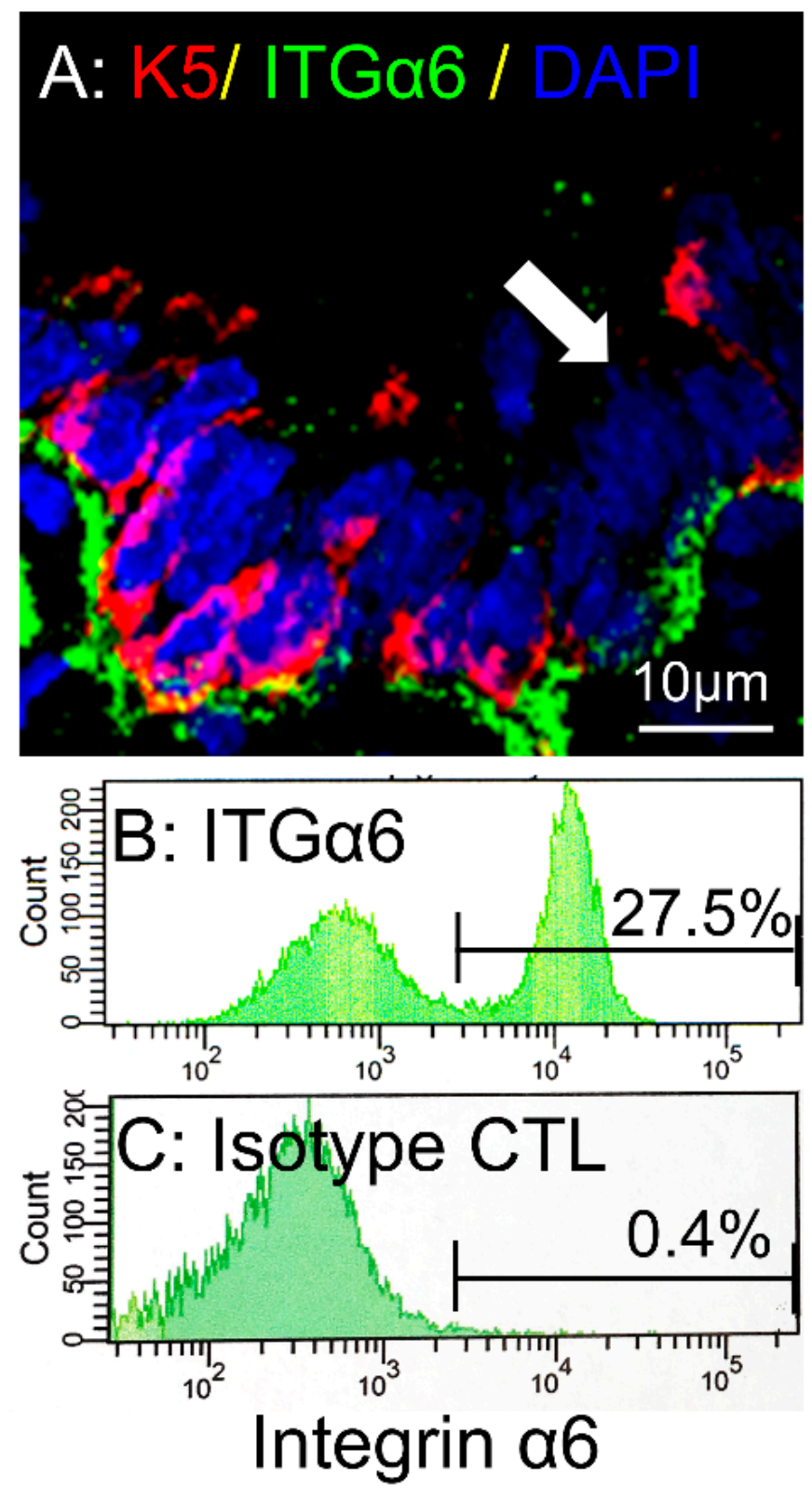

Figure 1. Identification of integrin (ITG) $\alpha 6^{+}$cells in the pig distal lung. (A): Pig distal lung was immunostained with Keratin 5 (K5, red), integrin (ITG) $\alpha 6$ (ITGa6, green), and DAPI (blue). Arrow indicates that ITG $\alpha 6^{+}$progenitor cells (green) are adjacent to $\mathrm{K}^{+}$(red) basal cells. (B): FACS assay for immunostained ITG $\alpha 6^{+}$cells among cultured small airway epithelial cells indicated that $27.5 \%$ of the cells are ITG $\alpha 6+$ basal cells. (C): FACS assay for isotype control antibody immunostained cells among cultured small airway epithelial cells. All the cells came from non-CF pigs. 


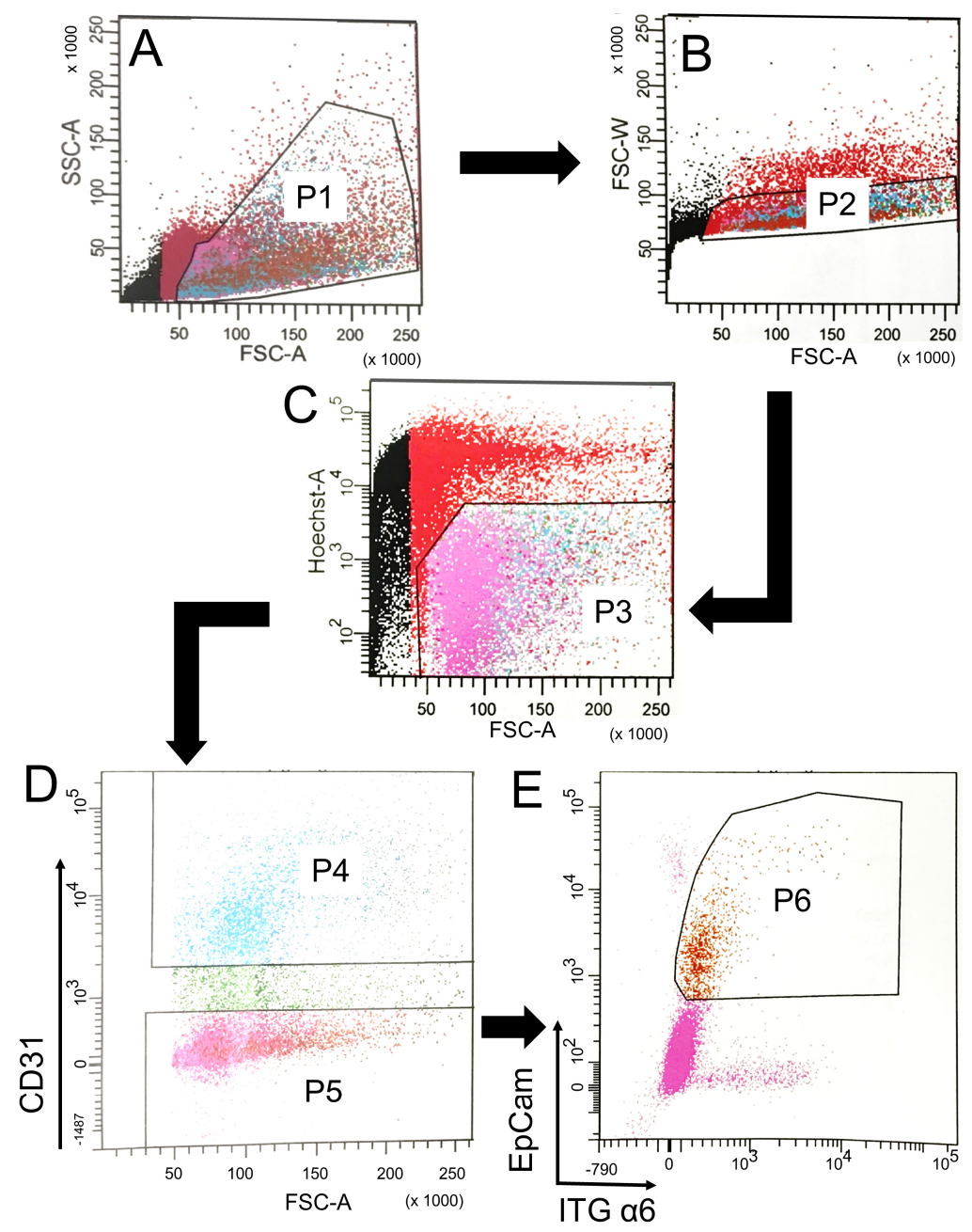

Figure 2. Isolation of ITG $\alpha 6^{+} / \mathrm{EPCAM}^{+} / \mathrm{CD} 31^{-}$progenitor cells in the pig distal lung. The surface expression of ITG $\alpha 6$, EPCAM and CD31 of single cells preparation isolated from a wide type pig lung was analyzed by FACS. (A) SSC vs. FSC density plot. P1 was gated for next step analysis. (B) FSC-Width vs. FSC-Area density plot. P2 was gated to exclude doublets for next step analysis (C) Hoechst 33258 was used to stain dead cells. P3 was gated to select live single cells for next step analysis. (D) CD31 ${ }^{+}$endothelial cells were excluded by P4 gate using FASC strategy. P5 was gated for next step analysis. Cells positive for both ITG $\alpha 6$ and EPCAM were identified as progenitor cells using P6 gate strategy (E). Black arrows indicate sequential workflow. All the cells came from non-CF pigs.

\subsection{Screening Reveals AAV Serotypes with High Transduction Efficiency for Pig DLEPS}

We serially screened both naturally occurring and novel AAV serotypes encoding eGFP to identify those which would best transduce pig DLEPs. We recently identified a novel AAV serotype, AAV2H22, which has high tropism for pig large and small airways, using a directed evolution technique [5,17]. AAV2H22 is identical to AAV2 except for five amino acid mutations in AAV2H22 (E67A, S207G, Q598L, I648V, and V708I) [5]. We screened AAV2H22 and five AAV2H22 derivatives, each with an individual back-mutation reverting their sequences to that of AAV2 at either A67E, G207S, L598Q, V648I, or I708V, for transduction efficiency on DLEPs. Conversely, we screened AAV2 and five AAV2 derivatives, each with one of the point-mutations (E67A, S207G, Q598L, I648V, and V708I) added to the AAV2 sequence. The DLPEs formed colonies from a single cell in the Matrigel 2 weeks after seeding. Figures S2 and S3 showed representative colonies transduced by AAV vectors. Other cells which did not get transduced by AAV vectors can be visualized by phase-contrast images and live fluorescence images for Hoechst-33342 dye. 
We found that AAV2H22 and its derivatives were superior to AAV2 and its derivative with higher transduction efficiency as measured by the percentage of GFP positive DLEPs (Figures 3 and 4). Finally, we screened natural serotypes AAV1, 2, 4, 5, 6, 8, 9, as well as AAV-DJ. Unexpectedly, we found AAV4 to have the highest transduction efficiency on DLEPs of all serotypes, including AAV2 and AAVH22 (Figure 5). We repeated the screening of all AAV vectors, and the results were presented in Figure S4. AAV4 had highest transduction efficiency among all the screened vectors.
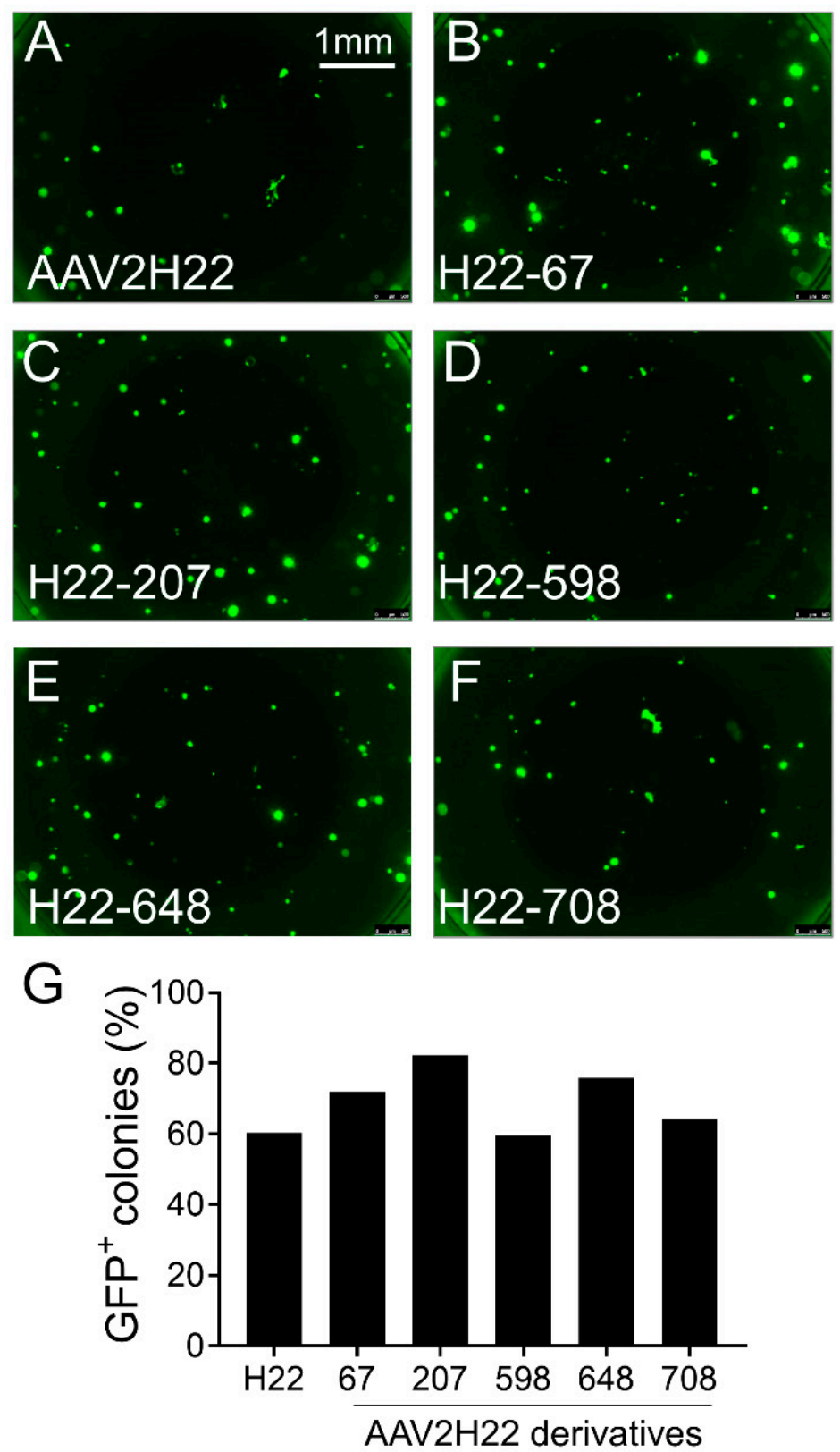

Figure 3. Screening AAV2H22 and derivatives for tropism for ITG $\alpha 6 \beta 4^{+}$pig progenitor cells. Freshly isolated ITG $\alpha 6 \beta 4^{+}$pig progenitor cells were transduced with the following viral vectors encoding eGFP: AAV2H22 (A), AAV2H22 derivatives viral vectors such as AAV2H22-E67A (B), AAV2H22-S207G (C), AAV2H22-Q598L (D), AAV2H22-I648V (E), AAV2H22-V708I (F). GFP cluster $^{+}$ were quantified after progenitor cells were cultured in the Matrigel for 2 weeks. The percentage of $\mathrm{GFP}^{+}$colonies among the entire progenitor cells for each viral vector were quantified $(\mathrm{G})$. All the cells came from non-CF pigs. Scale bars in all images $=1 \mathrm{~mm}$. 

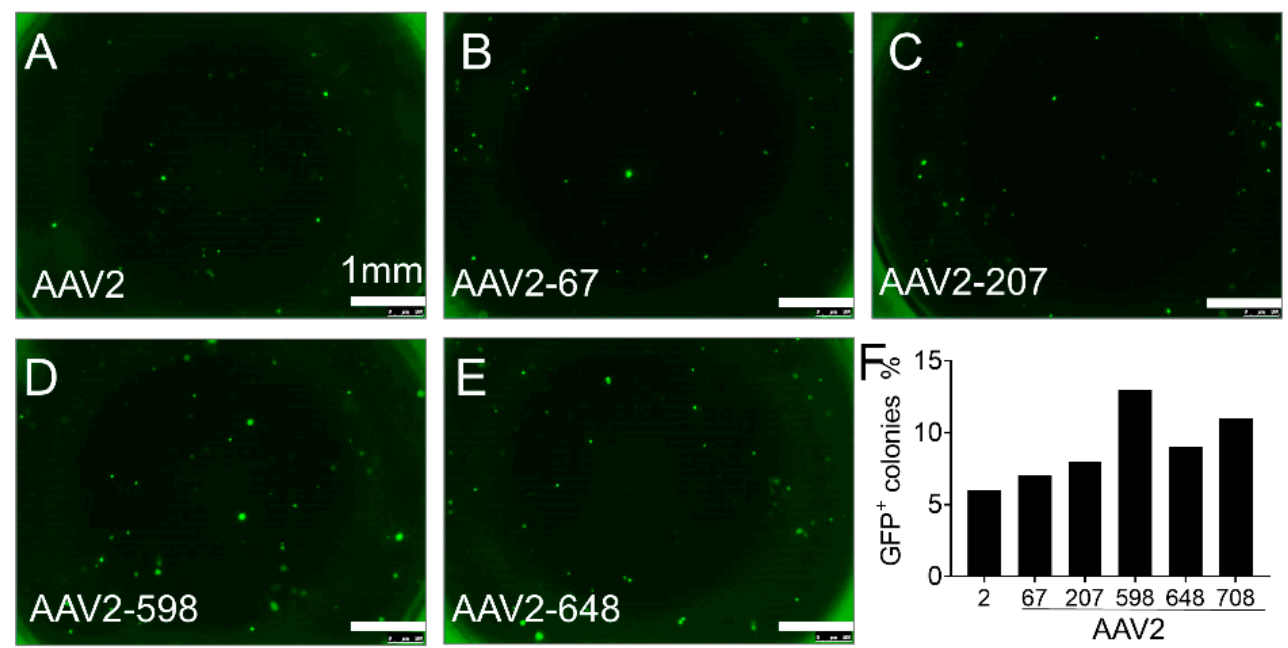

Figure 4. Screening AAV2 and derivatives for tropism for $\alpha 6 \beta 4^{+}$pig progenitor cells. Freshly isolated ITG $\alpha 6 \beta 4+$ pig progenitor cells were transduced with the following viral vectors encoding eGFP: AAV2 (A), AAV2 derivatives viral vectors including AAV2-E67A (B), AAV2-S207G (C), AAV2-Q598L (D), AAV2-I648V (E). GFP ${ }^{+}$clusters were quantified after progenitor cells were cultured in the Matrigel for 2 weeks. Quantification of the percentage of $\mathrm{GFP}^{+}$colonies among the entire progenitor cells for each viral vector shows maximum transduction efficiency was less than $15 \%(\mathbf{F})$. All the cells came from non-CF pigs. Scale bars in all images $=1 \mathrm{~mm}$.
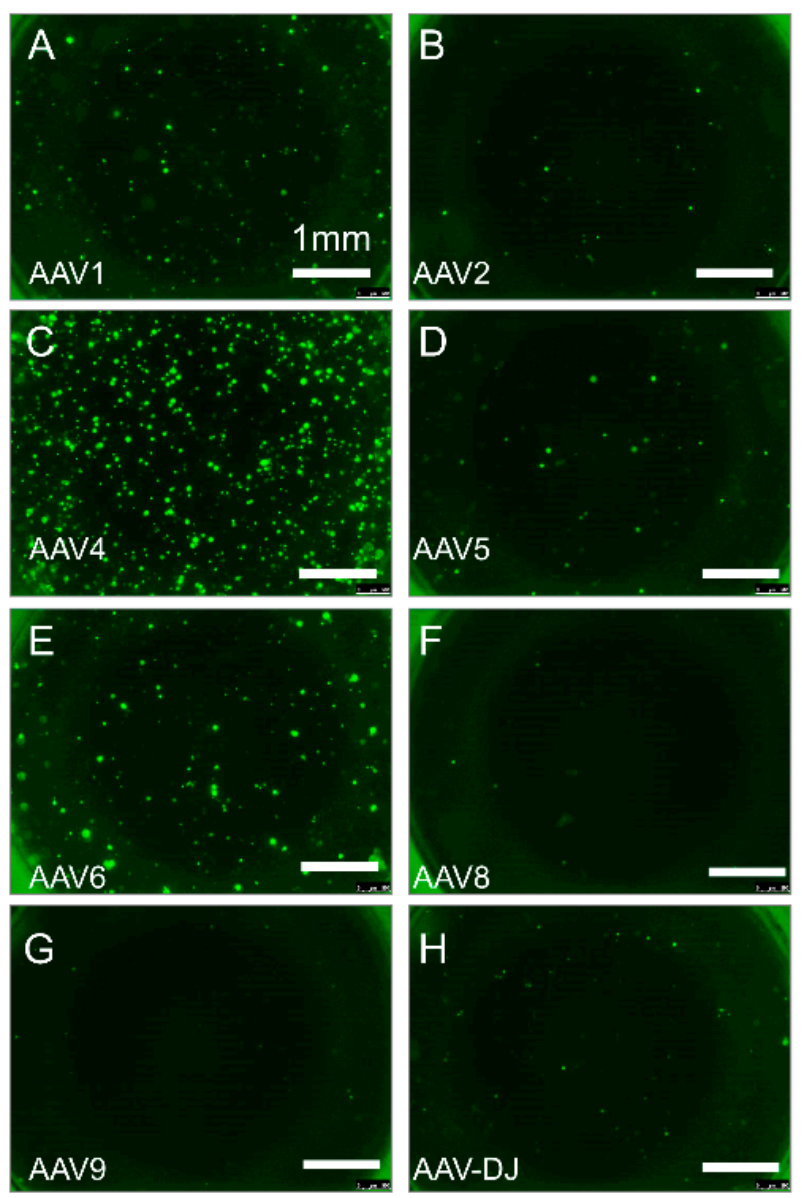

Figure 5. Cont.

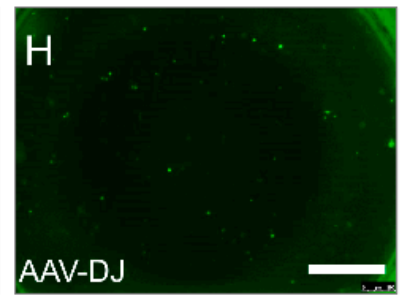

. 


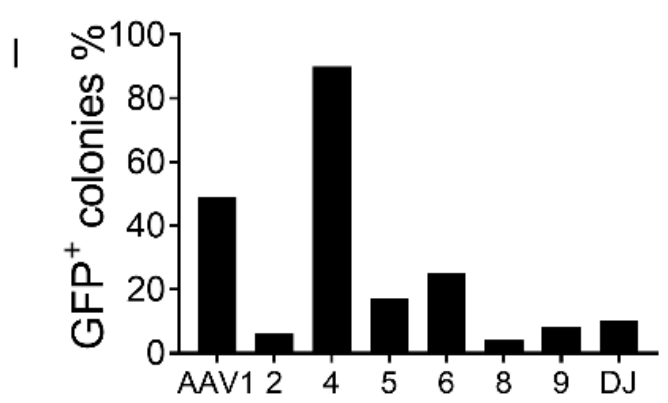

Figure 5. Screening AAV natural serotypes for tropism for $\alpha 6 \beta 4^{+}$pig progenitor cells and AAV4 was far superior to all other serotypes. Freshly isolated ITG $\alpha 6 \beta 4+$ pig progenitor cells were transduced with the following viral vectors encoding eGFP: AAV1 (A), AAV2 (B), AAV4 (C), AAV5 (D), AAV6 (E), AAV8 (F), AAV9 (G), AAV-DJ (H). GFP ${ }^{+}$clusters were quantified after progenitor cells were cultured in the Matrigel for 2 weeks. Quantification of the percentage of $\mathrm{GFP}^{+}$colonies among the entire progenitor cells for each viral vector shows that AAVV4 has the highest transduction efficiency (I). All the cells came from non-CF pigs. Scale bars in all images $=1 \mathrm{~mm}$.

\subsection{AAV4 Has Higher Tropism for Small Airway Epithelia Than Large Airway Epithelia in Pigs}

We next expanded studies to assess if AAV4 has tropism for other regions of the pig airways. We transduced primary large and small airway epithelia with AAV4-eGFP and quantified $\mathrm{GFP}^{+}$cells by manual counting two weeks later. AAV4 transduced both large and small airway epithelia (Figure 6). However, the relative transduction efficiency of AAV4 was about 10-fold higher for small airways compared with large airways, as measured by $\mathrm{GFP}^{+}$cells (Figure 6).
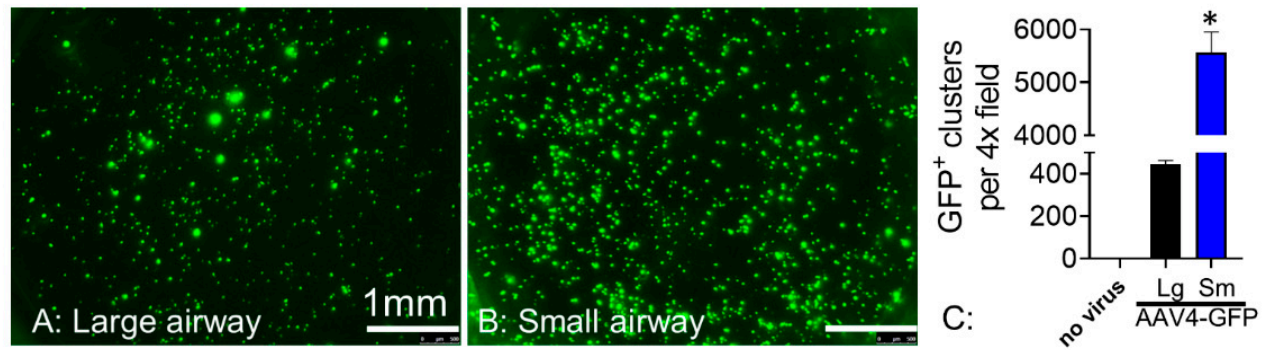

Figure 6. AAV4 transduce both large and small airway epithelial cells but with much higher tropism for small airways. AAV4 encoding eGFP transduces both large (A) and small (B) pig airway epithelial cells. Scale bars $=500 \mu \mathrm{m}$. (C) Quantification of AAV4-GFP transduced GFP ${ }^{+}$clusters demonstrate much higher expression in epithelial cells from pig small airways compared with large airways. $N=5, * p<0.05$ compared to large airways cells. All the cells came from non-CF pigs. Scale bars in all images $=1 \mathrm{~mm}$.

\subsection{Surface Carbohydrate Groups Are Differentially Expressed on Small Airway and Large Airway} Epithelia in Pigs

In order to investigate the molecular mechanism underlying the higher tropism of AAV4 for small airways compared to large airways, we performed lectin profile staining to detect the expression of specific groups of carbohydrates. O-linked $\alpha 2,3$ sialic acid is found on epithelial surface mucins, has been shown to bind AAV4, and suggested to prevent AAV4 apical entry into human airway cells [28]. Compared with large airways, porcine small airways express much less O-linked carbohydrates/O-glycoproteins and 2,3-linked sialic acid as demonstrated by fluorescence staining with jacalin and MMA, respectively (Figure 7). However, we found much higher expression levels of $\alpha$-mannose and N-acetyl-D-glucosamine sialic acid in small airways compared to large airways, after staining with ConA wheat germ agglutinin (WGA), respectively (Figure 7). These distinct lectin binding profiles may contribute to the differential transduction efficiencies of AAV4 on small compared with large airways in pigs. 

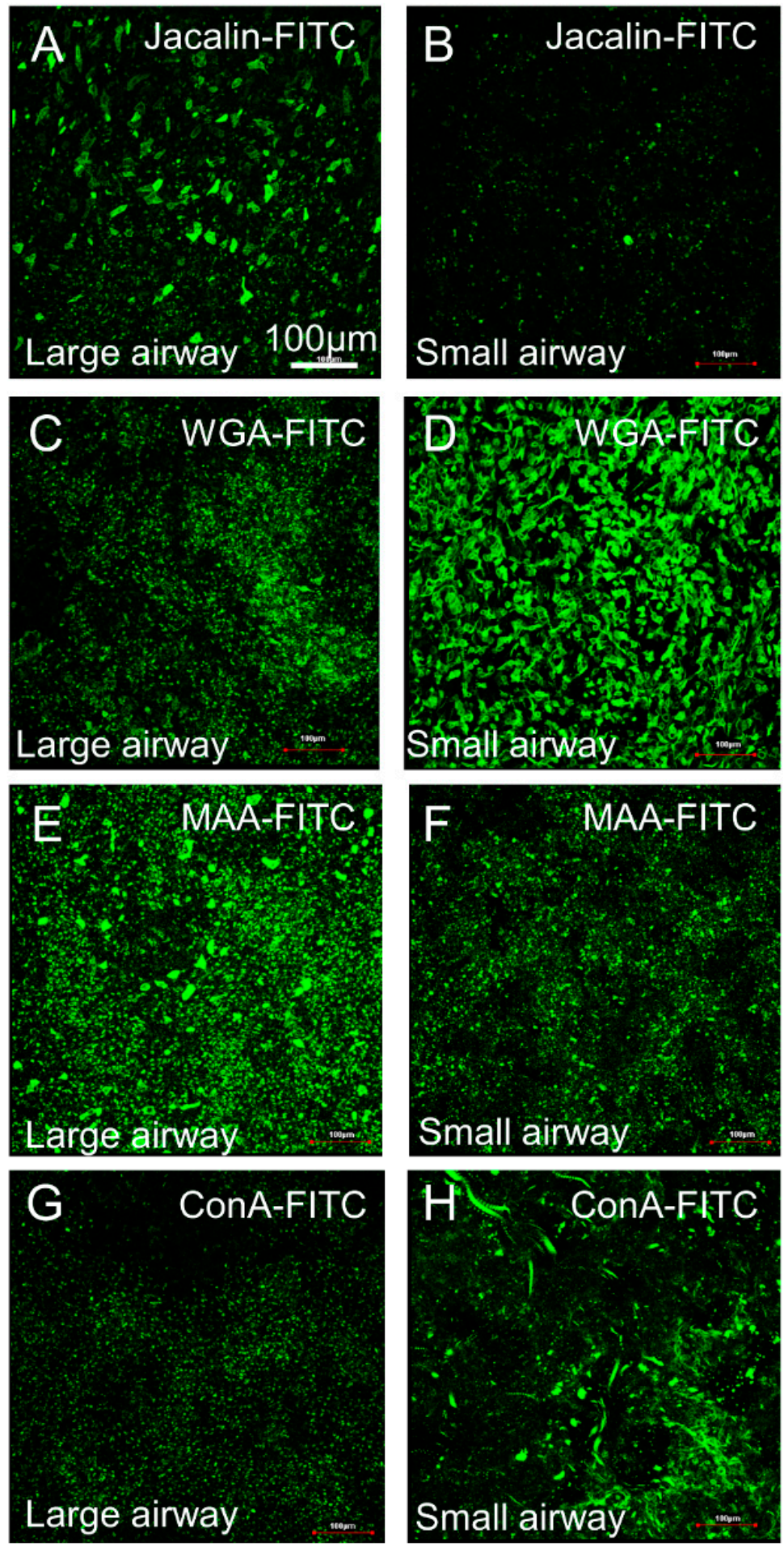

Figure 7. Lectin binding profiles assays in large and small porcine airway epithelium. There is much higher expression of O-linked carbohydrates and O-glycoproteins demonstrated by fluorescence assay for jacalin (A,B) in large airways compared with small airways. In contrast, there is much higher expression of N-acetyl-D-glucosamine demonstrated by wheat germ agglutinin assay (WGA, $(\mathbf{C}, \mathbf{D}))$ in small airways compared to large airways. In addition, there is more 2,3-linked sialic acid demonstrated by MAA (E,F) fluorescence assay in large airways compared to small airways. Moreover, there is more mannose demonstrated by ConA $(\mathbf{G}, \mathbf{H})$ fluorescence assay in small airways compared to large airways. All the cells came from non-CF pigs. 


\subsection{AAV4-CFTR Transduction of CF Pig Small Airway Epithelia Increases CFTR Activity and Expression}

AAV packaging limitations prohibit cloning the full length CFTR cDNA and key regulatory domains into a recombinant AAV. Hence, a shortened AAV expression cassette for CFTR gene transfer to airway epithelia was developed which contains an optimized truncated CMV promoter and polyA sequence along with a CFTR CDNA lacking residues 708-759 of the regulatory domain (CFTR $\triangle R$ ) [37]. This CFTR variant shows normal biosynthesis, apical membrane targeting, and $\mathrm{Cl}^{-}$channel activity [37]. We have generated an AAV4 vector encoding pig CFTR with $R$ domain deletion controlled by the partial CMV promoter (AAV4-CMV > pCFTR). We transduced cultured CF small airway epithelia with AAV4-CMV > pCFTR or AAV4-CMV-eGFP to determine if AAV4 can be used as a delivery vector for CFTR. Then, two weeks after viral transduction, AAV4 encoding CFTR significantly increased cAMP stimulated short-circuit current (Isc) and CFTR gene expression in CF pig airway epithelia in vitro (Figure 8), demonstrating that AAV4 can be used as a delivery vector for CFTR for CF gene therapy.
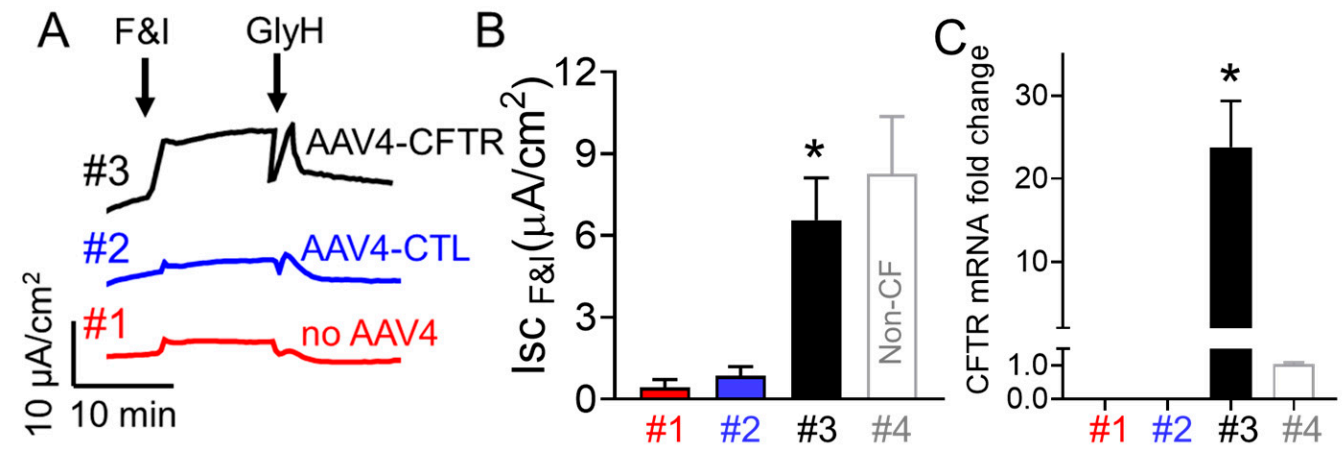

Figure 8. AAV4 encoding CFTR significantly increased cAMP stimulated short circuit current (Isc) and CFTR gene expression in CF pig small airway epithelia. (A) Sample Ussing chamber traces from small airway epithelial cells from CF pigs in response to indicated chemical treatments. Trace \#1: control without AAV4 treatment; \#2: CF cells treated with AAV4 encoding GFP; \#3: CF cells treated with AAV4 encoding CFTR. (B) Summary of cAMP stimulated Isc. $N=3,{ }^{*} p<0.05$ compared to \#1 and \#2. \#4, non-CF cells. (C) AAV4 encoding CFTR increased CFTR expression in CF cells. $N=3$. * $p<0.05$ compared to \#1 and \#2. \#4, non-CF cells.

\subsection{In Vivo Airway Administered AAV4 Targets the Distal Small Airways in Pigs}

Delivering transgenes in vivo has been a central challenge to gene therapy for $\mathrm{CF}$ lung disease. Pig lungs are anatomically and structurally similar to human lungs, and pigs are an ideal preclinical and translational model for CFTR gene therapy [15]. To explore the feasibility of viral delivery to the small airway in vivo, we monitored the distribution of CT imaging contrast agent instilled via bronchoscope to the left lung. Analysis of images from different view demonstrated that the contrast agent reached to the distal left lung, with broad distribution (Figure S5). We assessed the efficiency of cell targeting by AAV4 encoding eGFP following in vivo viral delivery to farm pigs. AAV4-CMV > eGFP was administered by airway instillation to both the trachea and distal lung. Then, two weeks later, lung tissue was fixed for immunofluorescent imaging. GFP transferred from AAV4 was detected in cells harvested from the small airways and the bronchoalveolar junction area, but rarely in the large airways (Figure 9). These results suggest that AAV4 has much higher tropism for small airways than for large airways. The ability of AAV4 to deliver target genes to small airways which play an important role in early CF pathogenesis urges future preclinical studies in CF pigs in vivo, and potential translational studies in humans. 

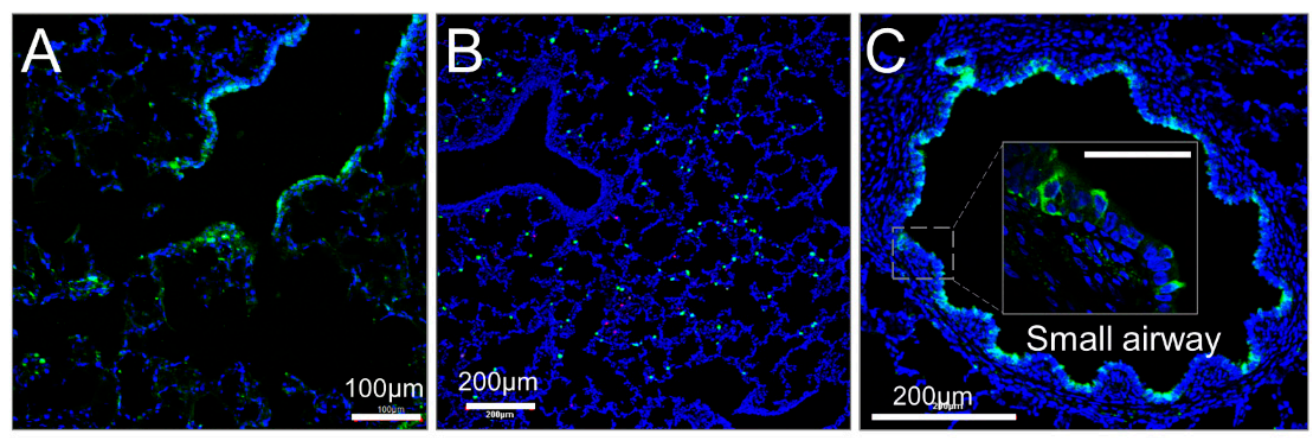

Figure 9. AAV4-mediated transgene expression in pig distal lung. AAV4-CMV > eGFP was administered via bronchoscope to pig distal lung. Immunofluorescent imaging of tissue confirmed expression of $\mathrm{GFP}^{+}$cells in bronchioalveolar junction (A), alveolar region (B), and small airways (C) in vivo. All the images came from non-CF pigs. $N=3$.

\section{Discussion}

Our analysis of AAV natural serotypes using cultured primary pig airway epithelia showed that AAV4 has high tropism for pig airway epithelia, with higher transduction efficiency in small airways compared to large airways. The higher efficiency in small airways is likely due to decreased mucin expression there, and because the different sialic acids (such as $\alpha$-mannose and $N$-acetyl-D-glucosamine sialic acids) glycosylated mucins does not inhibit AAV4 transduction there [6,40,41]. Previous studies also reported that the linkage and distribution of sialic acid are vastly different in pig large and small airways [42].

Moreover, AAV4 is part of an evolutionary AAV lineage that does not require AAV receptor [43], and we have shown that vectors capable of AAV receptor-independent infection more efficiently transduce airway epithelia from apical side [44]. In addition, AAV4-mediated delivery of CFTR increased $\mathrm{Cl}^{-}$transport in CF pig small airway epithelium in vitro. Hence AAV4, with much higher tropism for small airway epithelia compared with large airways, will enable us to mechanistically investigate what has been suggested by clinical findings, namely that small airways play an important role in $\mathrm{CF}$ pathogenesis [7].

Our study focuses on small airways, which are likely the key sites of CFTR expression due to distinct features including increased CFTR activity and higher $\mathrm{pH}$ of air surface liquid compared with large airways [6]. Clinical studies also suggest small airways are a key region involved in the early manifestations of CF lung disease. For example, in CF children the FEF 25-75 marker of small airway obstruction usually declines before large airway FEV1 indications. Yet, due to the inaccessibility of small airways in CF patients, there are currently few published studies investigating how CFTR affects small airways. Moreover, an CF animal model recapitulating human anatomy and physiology beginning at birth has only recently become available, with the development of the CF pig model by our group.

Progress has been made in developing CFTR correctors and potentiators to treat many people with CFTR mutations, but there has been no therapy to restore CFTR function irrespective of the mutations [3,45-47]. Efficient targeted delivery of CFTR cDNA to CF lungs might correct the CFTR defect, restore host defense mechanisms, and prevent lung infections [15,48]. The CF pig model provides a new, and uniquely valuable opportunity to investigate novel viral-based gene therapy approaches to prevent CF lung disease.

$\mathrm{CF}$ pigs develop the characteristic manifestations of human $\mathrm{CF}$, including abnormalities of the pancreas, lung, intestine, liver, and other organs. Moreover, spontaneous bacterial airway infections emerge in CF pig lungs [2]. We have detected host defense defects in both large and small airways in CF pigs, at least partially due to ASL pH dysregulation. Compared to non-CF animals, the large airways of newborn $\mathrm{CF}$ pigs have a reduced airway surface liquid (ASL) pH in vivo, ex vivo, and in differentiated primary cultures of airway epithelia. These findings prompted us to investigate the nasal $\mathrm{pH}$ in newborn babies with 
$\mathrm{CF}$, where we found nasal ASL was also more acidic than in non-CF neonates. Moreover, the ATP12A proton pump acidifies the large airways, and lack of ATP12A expression in CF mice may explain, at least in part, the lack of a lung phenotype [49]. In our recent studies, the ASL from CF distal small airways were nevertheless more acidic compared to non-CF although porcine small airway tissue does not express ATP12A (like mice). We further found that small airways express ATP6V0D2, an isoform of the V0d subunit of the $\mathrm{H}^{+}$-translocating plasma membrane V-type ATPase to the apical surface only when the $\mathrm{pH}$ is alkaline [50]. Similar to the large airways, CF small airways exhibit a defect in mucociliary clearance only detectable when stimulated to secret mucus. Future work using AAV4 to restore CFTR function or knockdown ATP6V0D2 function in CF small airways will facilitate mechanistic studies of small airway biology ex vivo or in vivo, and open up novel avenues for CF treatments.

Additionally, the knowledge generated by this study will allow AAV4 to be used as a research tool in pigs to develop models for lung diseases apart from CF. The advantages of using pigs as preclinical models include: (1) The pig lung epithelial ion composition is more similar to those found in human lungs than are rodent compositions; (2) Pig organs share many anatomical, histological, physiological, and biochemical responses with human organs and have been used in biomedical research for multiple human diseases [51]; (3) The body size of a pig provides the opportunity to collect enough samples, as well as obtain adequate lung computed tomography (CT) imaging resolution. Hogg et al. [52,53] have shown that the destruction of small airways precedes the development of emphysema, AAV4-mediated suicide gene delivery to small airways in pigs could determine whether induced-small airway injury is causative for COPD-like lung diseases. Moreover, AAV4 was superior to all other AAV natural serotypes in transducing ITG $\alpha 6 \beta 4^{+}$pig distal lung progenitor cells and will be a useful tool to study pathogenesis of common pig respiratory diseases, such as swine influenza.

Supplementary Materials: The following are available online at https: / www.mdpi.com/article/10 .3390 / cells10051014/s1, Figure S1: Schematic workflow for isolation of large, small airway epithelial cells and distal lung progenitor cells from pig lungs. Figure S2: Transduction of distal lung progenitor cells by AAV vectors. Figure S3: Transduction of distal lung progenitor cells by AAV vectors. Figure S4: The second run of screening of AAV vectors for tropism for ITG $\alpha 6 \beta 4+$ pig progenitor cells. Figure S5: The feasibility of delivery of AAV vectors to small airways in vivo.

Author Contributions: Conceptualization: X.L., and J.Z.; Methodology: X.L., M.A.A., J.Z.; Formal Analysis: X.L., O.G.C., S.E.M., C.M.B., A.E.; Investigation: X.L., O.G.C., S.E.M., C.M.B., A.E., R.V., M.A.A., B.A.H., R.E.G.; Resources: X.L., J.Z., D.A.S.; Data Curation: X.L., O.G.C., S.E.M., C.M.B., A.E.; Writing-Original Draft: X.L., J.Z.; Writing—Review and Editing: All authors; Visualization: X.L., J.Z.; Supervision: X.L., J.Z.; Funding Acquisition: X.L., D.A.S., J.Z. All authors have read and agreed to the published version of the manuscript.

Funding: This work was funded by the National Institutes of Health (HL091842 and HL51670 to J.Z. and D.A.S.) and by The Cystic Fibrosis Foundation (LIX15XX0, LiX16G0, LI19XX0, STOLTZ19R0) and Spectrum Health-MSU Alliance Corporation funds.

Institutional Review Board Statement: The study was approved by the Animal Care and Use Committees of University of Iowa (protocol \#6031677-015 and date of approval: 1 April 2016) and Michigan State University (protocol \# 2019-020 and date of approval: 6 September 2019).

Informed Consent Statement: Not applicable.

Data Availability Statement: The data presented in this study are available on request from the corresponding authors.

Acknowledgments: We thank Michael Welsh, Peter Taft, Linda Powers, and Mallory Stroik for excellent technical assistance, valuable suggestions and advice. We thank the University of Iowa in vitro models and cell culture core for providing equipment and necessary materials to perform these experiments. The data presented herein were obtained at the Flow Cytometry Facility, which is a Carver College of Medicine/Holden Comprehensive Cancer Center core research facility at the 
University of Iowa. The facility is funded through user fees and the generous financial support of the Carver College of Medicine, Holden Comprehensive Cancer Center, and Iowa City Veteran's Administration Medical Center.

Conflicts of Interest: The authors declare no conflict of interest. The funders had no role in the design of the study; in the collection, analyses, or interpretation of data; in the writing of the manuscript, or in the decision to publish the results.

\begin{tabular}{|c|c|}
\hline \multicolumn{2}{|c|}{ Abbreviations } \\
\hline & abbreviations are used in th \\
\hline AAV4 & Adeno-associated virus 4 \\
\hline $\mathrm{CF}$ & Cystic fibrosis \\
\hline CFTR & $\mathrm{CF}$ transmembrane conductance regulator \\
\hline FEV1 & Forced Expiratory Volume in $1 \mathrm{~s}$ \\
\hline COPD & Chronic Obstructive Pulmonary Disease \\
\hline DLEPs & Distal lung epithelial progenitors \\
\hline ITG & Integrin \\
\hline FACS & Fluorescence-activated cell sorting \\
\hline ConA & Concanavalin A \\
\hline MMA & Maakia amurensis lectin \\
\hline
\end{tabular}

\section{References}

1. Welsh, M.J.; Smith, A.E. Cystic fibrosis. Sci. Am. 1995, 273, 52-59. [CrossRef]

2. Stoltz, D.A.; Meyerholz, D.K.; Welsh, M.J. Origins of cystic fibrosis lung disease. N. Engl. J. Med. 2015, 372, 351-362. [CrossRef] [PubMed]

3. Wainwright, C.E.; Elborn, J.S.; Ramsey, B.W.; Marigowda, G.; Huang, X.; Cipolli, M.; Colombo, C.; Davies, J.C.; De Boeck, K.; Flume, P.A.; et al. Lumacaftor-ivacaftor in patients with cystic fibrosis homozygous for Phe508del CFTR. N. Engl. J. Med. 2015, 373, 220-231. [CrossRef] [PubMed]

4. Stoltz, D.A.; Meyerholz, D.K.; Pezzulo, A.A.; Ramachandran, S.; Rogan, M.P.; Davis, G.J.; Hanfland, R.A.; Wohlford-Lenane, C.; Dohrn, C.L.; Bartlett, J.A.; et al. Cystic fibrosis pigs develop lung disease and exhibit defective bacterial eradication at birth. Sci. Transl. Med. 2010, 2, 29ra31. [CrossRef] [PubMed]

5. $\quad$ Steines, B.; Dickey, D.D.; Bergen, J.; Excoffon, K.J.D.A.; Weistein, J.R.; Li, X.; Yan, Z.; Alaiwa, M.H.A.; Shah, V.S.; Bouzek, D.C.; et al. CFTR gene transfer with AAV improves early cystic fibrosis pig phenotypes. JCI Insight 2016, 1, e88728. [CrossRef]

6. $\quad$ Li, X.; Tang, X.X.; Vargas Buonfiglio, L.G.; Comellas, A.P.; Thornell, I.M.; Ramachandran, S.; Karp, P.H.; Taft, P.J.; Sheets, K.; Alaiwa, M.H.A.; et al. Electrolyte transport properties in distal small airways from cystic fibrosis pigs with implications for host defense. Am. J. Physiol. Lung Cell. Mol. Physiol. 2016, 310, L670-L679. [CrossRef]

7. Tiddens, H.A.; Donaldson, S.H.; Rosenfeld, M.; Pare, P.D. Cystic fibrosis lung disease starts in the small airways: Can we treat it more effectively? Pediatr. Pulmonol. 2010, 45, 107-117. [CrossRef]

8. Esterly, J.R.; Oppenheimer, E.H. Cystic fibrosis of the pancreas: Structural changes in peripheral airways. Thorax 1968, 23, 670-675. [CrossRef]

9. Bedrossian, C.W.; Greenberg, S.D.; Singer, D.B.; Hansen, J.J.; Rosenberg, H.S. The lung in cystic fibrosis. A quantitative study including prevalence of pathologic findings among different age groups. Hum. Pathol. 1976, 7, 195-204. [CrossRef]

10. Oppenheimer, E.H.; Esterly, J.R. Pathology of cystic fibrosis review of the literature and comparison with 146 autopsied cases. Perspect. Pediatr. Pathol. 1975, 2, 241-278.

11. Sobonya, R.E.; Taussig, L.M. Quantitative aspects of lung pathology in cystic fibrosis. Am. Rev. Respir. Dis. 1986, 134, 290-295.

12. Bakker, E.M.; Borsboom, G.J.; van der Wiel-Kooij, E.C.; Caudri, D.; Rosenfeld, M.; Tiddens, H.A. Small airway involvement in cystic fibrosis lung disease: Routine spirometry as an early and sensitive marker. Pediatr. Pulmonol. 2013, 48, 1081-1088. [CrossRef] [PubMed]

13. Tiddens, H.A.; Koopman, L.P.; Lambert, R.K.; Elliott, W.M.; Hop, W.C.; van der Mark, T.W.; de Boer, W.J.; de Jongste, J.C. Cartilaginous airway wall dimensions and airway resistance in cystic fibrosis lungs. Eur. Respir. J. 2000, 15, 735-742. [CrossRef] [PubMed]

14. Yan, Z.; Stewart, Z.A.; Sinn, P.L.; Olsen, J.C.; Hu, J.; McCray, P.B.; Engelhardt, J.F. Ferret and pig models of cystic fibrosis: Prospects and promise for gene therapy. Hum. Gene Ther. Clin. Dev. 2015, 26, 38-49. [CrossRef]

15. Yan, Z.; McCray, P.B., Jr.; Engelhardt, J.F. Advances in gene therapy for cystic fibrosis lung disease. Hum. Mol. Genet. 2019, 28, R88-R94. [CrossRef]

16. Oakland, M.; Sinn, P.L.; McCray, P.B., Jr. Advances in cell and gene-based therapies for cystic fibrosis lung disease. Mol. Ther. 2012, 20, 1108-1115. [CrossRef] 
17. Excoffon, K.J.; Koerber, J.T.; Dickey, D.D.; Murthda, M.; Keshavjee, S.; Kaspar, B.K.; Zabner, J.; Schaffer, D.V. Directed evolution of adeno-associated virus to an infectious respiratory virus. Proc. Natl. Acad. Sci. USA 2009, 106, 3865-3870. [CrossRef]

18. Zaiss, A.K.; Liu, Q.; Bowen, G.P.; Wong, N.C.; Bartlett, J.S.; Muruve, D.A. Differential activation of innate immune responses by adenovirus and adeno-associated virus vectors. J. Virol. 2002, 76, 4580-4590. [CrossRef]

19. Keswani, S.G.; Balaji, S.; Le, L.; Leung, A.; Katz, A.B.; Lim, F.-Y.; Habli, M.; Jones, H.N.; Wilson, J.M.; Crombleholme, T.M. Pseudotyped AAV vector-mediated gene transfer in a human fetal trachea xenograft model: Implications for in utero gene therapy for cystic fibrosis. PLoS ONE 2012, 7, e43633. [CrossRef]

20. Limberis, M.P.; Vandenberghe, L.H.; Zhang, L.; Pickles, R.J.; Wilson, J.M. Transduction efficiencies of novel AAV vectors in mouse airway epithelium in vivo and human ciliated airway epithelium in vitro. Mol. Ther. 2009, 17, 294-301. [CrossRef]

21. Bals, R.; Xiao, W.; Sang, N.; Weiner, D.J.; Meegalla, R.L.; Wilson, J.M. Transduction of well-differentiated airway epithelium by recombinant adeno-associated virus is limited by vector entry. J. Virol. 1999, 73, 6085-6088. [CrossRef]

22. Sirninger, J.; Muller, C.; Braag, S.; Tang, Q.; Yue, H.; Detrisac, C.; Ferkol, T.; Guggino, W.B.; Flotte, T.R. Functional characterization of a recombinant adeno-associated virus 5-pseudotyped cystic fibrosis transmembrane conductance regulator vector. Hum. Gene Ther. 2004, 15, 832-841.

23. Zabner, J.; Seiler, M.; Walters, R.; Kotin, R.M.; Fulgeras, W.; Davidson, B.L.; Chiorini, J.A. Adeno-associated virus type 5 (AAV5) but not AAV2 binds to the apical surfaces of airway epithelia and facilitates gene transfer. J. Virol. 2000, 74, 3852-3858. [CrossRef]

24. Fischer, A.C.; Smith, C.I.; Cebotaru, L.; Zhang, X.; Askin, F.B.; Wright, J.; Guggino, S.E.; Adams, R.J.; Flotte, T.; Guggino, W.B. Expression of a truncated cystic fibrosis transmembrane conductance regulator with an AAV5-pseudotyped vector in primates. Mol. Ther. 2007, 15, 756-763. [CrossRef]

25. Song, Y.; Lou, H.H.; Boyer, J.L.; Limberis, M.P.; Vandenberghe, L.H.; Hackett, N.R.; Leopold, P.L.; Wilson, J.M.; Crystal, R.G. Functional cystic fibrosis transmembrane conductance regulator expression in cystic fibrosis airway epithelial cells by AAV6.2-mediated segmental trans-splicing. Hum. Gene Ther. 2009, 20, 267-281. [CrossRef]

26. Li, W.; Zhang, L.; Johnson, J.S.; Zhijian, W.; Grieger, J.C.; Ping-Jie, X.; Drouin, L.M.; Agbandje-McKenna, M.; Pickles, R.J.; Samulski, R.J. Generation of novel AAV variants by directed evolution for improved CFTR delivery to human ciliated airway epithelium. Mol. Ther. 2009, 17, 2067-2077. [CrossRef]

27. Dickey, D.D.; Excoffon, K.J.; Koerber, J.T.; Bergen, J.; Steines, B.; Klesney-Tait, J.; Schaffer, D.V.; Zabner, J. Enhanced sialic acid-dependent endocytosis explains the increased efficiency of infection of airway epithelia by a novel adeno-associated virus. J. Virol. 2011, 85, 9023-9030. [CrossRef] [PubMed]

28. Walters, R.W.; Pilewski, J.M.; Chiorini, J.A.; Zabner, J. Secreted and transmembrane mucins inhibit gene transfer with AAV4 more efficiently than AAV5. J. Biol. Chem. 2002, 277, 23709-23713. [CrossRef]

29. Zincarelli, C.; Soltys, S.; Rengo, G.; Rabinowitz, J.E. Analysis of AAV serotypes 1-9 mediated gene expression and tropism in mice after systemic injection. Mol. Ther. 2008, 16, 1073-1080. [CrossRef]

30. Grimm, D.; Zhou, S.; Nakai, H.; Thomas, C.E.; Storm, T.A.; Fuess, S.; Matsushita, T.; Allen, J.; Surosky, R.; Lochrie, M.; et al. Preclinical in vivo evaluation of pseudotyped adeno-associated virus vectors for liver gene therapy. Blood 2003, 102, $2412-2419$. [CrossRef]

31. Chen, H.; Matsumoto, K.; Brockway, B.L.; Rackley, C.R.; Liang, J.; Lee, J.-H.; Jiang, D.; Noble, P.W.; Randell, S.H.; Kim, C.F.; et al. Airway epithelial progenitors are region specific and show differential responses to bleomycin-induced lung injury. Stem Cells 2012, 30, 1948-1960. [CrossRef]

32. Reynolds, S.D.; Brechbuhl, H.M.; Smith, M.K.; Smith, R.W.; Ghosh, M. Lung epithelial healing: A modified seed and soil concept. Proc. Am. Thorac. Soc. 2012, 9, 27-37. [CrossRef]

33. Li, X.; Rossen, N.; Sinn, P.L.; Hornick, A.L.; Steines, B.R.; Karp, P.H.; Ernst, S.E.; Adam, R.J.; Moninger, T.O.; Levasseur, D.N.; et al. Integrin $\alpha 6 \beta 4$ identifies human distal lung epithelial progenitor cells with potential as a cell-based therapy for cystic fibrosis lung disease. PLOS ONE 2013, 8, e83624. [CrossRef]

34. Chapman, H.A.; Li, X.; Alexander, J.P.; Brunwell, A.; Lorizio, W.; Tan, K.; Sonnenberg, A.; Wei, Y.; Vu, T.H. Integrin $\alpha 6 \beta 4$ identifies an adult distal lung epithelial population with regenerative potential in mice. J. Clin. Investig. 2011, 121, 2855-2862. [CrossRef]

35. Karp, P.H.; Moninger, T.O.; Weber, S.P.; Nesselhauf, T.S.; Launspach, J.L.; Zabner, J.; Welsh, M.J. An in vitro model of differentiated human airway epithelia. Methods for establishing primary cultures. Methods Mol. Biol. 2002, 188, 115-137.

36. Zabner, J.; Wadsworth, S.C.; Smith, A.E.; Welsh, M.J. Adenovirus-mediated generation of cAMP-stimulated Cl- transport in cystic fibrosis airway epithelia in vitro: Effect of promoter and administration method. Gene Ther. 1996, 3, 458-465.

37. Ostedgaard, L.S.; Rokhlina, T.; Karp, P.H.; Lashmit, P.; Afione, S.; Schmidt, M.; Zabner, J.; Stinski, M.F.; Chiorini, J.A.; Welsh, M.J. A shortened adeno-associated virus expression cassette for CFTR gene transfer to cystic fibrosis airway epithelia. Proc. Natl. Acad. Sci. USA 2005, 102, 2952-2957. [CrossRef]

38. Zhang, L.N.; Karp, P.; Gerard, C.J.; Pastor, E.; Laux, D.; Munson, K.; Yan, Z.; Liu, X.; Godwin, S.; Thomas, C.P.; et al. Dual therapeutic utility of proteasome modulating agents for pharmaco-gene therapy of the cystic fibrosis airway. Mol. Ther. 2004, 10, 990-1002. [CrossRef]

39. Dickey, D.D.; Excoffon, K.J.; Young, K.R.; Parekh, K.R.; Zabner, J. Hoechst increases adeno-associated virus-mediated transgene expression in airway epithelia by inducing the cytomegalovirus promoter. J. Gene Med. 2012, 14, 366-373. [CrossRef] 
40. Okuda, K.; Chen, G.; Subramani, D.B.; Wolf, M.; Gilmore, R.C.; Kato, T.; Radicioni, G.; Kesimer, M.; Chua, M.; Dang, H.; et al. Localization of secretory mucins MUC5AC and MUC5B in normal/healthy human airways. Am. J. Respir. Crit. Care Med. 2019, 199, 715-727. [CrossRef] [PubMed]

41. Widdicombe, J.H.; Wine, J.J. Airway gland structure and function. Physiol. Rev. 2015, 95, 1241-1319. [CrossRef] [PubMed]

42. Nelli, R.K.; Kuchipudi, S.V.; White, G.A.; Perez, B.B.; Dunham, S.P.; Chang, K.C. Comparative distribution of human and avian type sialic acid influenza receptors in the pig. BMC Vet. Res. 2010, 6, 4. [CrossRef]

43. Dudek, A.M.; Pillay, S.; Puschnik, A.S.; Nagamine, C.M.; Cheng, F.; Qiu, J.; Carette, J.E.; Vandenberghe, L.H. An alternate route for adeno-associated virus (AAV) entry independent of AAV receptor. J. Virol. 2018, 92, e02213-e02217. [CrossRef]

44. Hamilton, B.A.; Li, X.; Pezzulo, A.A.; Abou Alaiwa, M.H.; Zabner, J. Polarized AAVR expression determines infectivity by AAV gene therapy vectors. Gene Ther. 2019, 26, 240-249. [CrossRef]

45. Davies, J.C.; Moskowitz, S.M.; Brown, C.; Horsley, A.; Mall, M.A.; McKone, E.F.; Plant, B.J.; Prais, D.; Ramsey, B.W.; Taylor-Cousar, J.L.; et al. VX-659-tezacaftor-ivacaftor in patients with cystic fibrosis and one or two Phe508del alleles. N. Engl. J. Med. 2018, 379, 1599-1611. [CrossRef]

46. Keating, D.; Marigowda, G.; Burr, L.; Daines, C.; Mall, M.A.; McKone, E.F.; Ramsey, B.M.; Rowe, S.M.; Sass, L.A.; Tullis, E.; et al. VX-445-tezacaftor-ivacaftor in patients with cystic fibrosis and one or two Phe508del alleles. N. Engl. J. Med. 2018, 379, 1612-1620. [CrossRef]

47. Bear, C.E. A therapy for most with cystic fibrosis. Cell 2020, 180, 211. [CrossRef]

48. Roesch, E.A.; Drumm, M.L. Powerful tools for genetic modification: Advances in gene editing. Pediatr. Pulmonol. 2017, 52, S15-S20. [CrossRef] [PubMed]

49. Shah, V.S.; Meyerholz, D.K.; Tang, X.X.; Reznikov, L.; Alaiwa, M.A.; Ernst, S.E.; Karp, P.H.; Wohlford-Lenane, C.L.; Heilmann, K.P.; Leidinger, M.R.; et al. Airway acidification initiates host defense abnormalities in cystic fibrosis mice. Science 2016, 351, 503-507. [CrossRef]

50. Li, X.; Villacreses, R.; Thornell, I.M.; Noriega, J.; Mather, S.; Brommel, C.M.; Lu, L.; Zabner, A.; Ehler, A.; Meyerholz, D.K.; et al. V-type ATPase mediates airway surface liquid acidification in pig small airway epithelial cells. Am. J. Respir. Cell Mol. Biol. 2021. [CrossRef] [PubMed]

51. Swindle, M.M.; Makin, A.; Herron, A.J.; Clubb, F.J., Jr.; Frazier, K.S. Swine as models in biomedical research and toxicology testing. Vet. Pathol. 2012, 49, 344-356. [CrossRef] [PubMed]

52. Hogg, J.C.; Macklem, P.T.; Thurlbeck, W.M. Site and nature of airway obstruction in chronic obstructive lung disease. N. Engl. J. Med. 1968, 278, 1355-1360. [CrossRef]

53. Koo, H.K.; Vasilescu, D.M.; Booth, S.; Hsieh, A.; Katsamenis, O.L.; Fishbane, N.; Elliott, W.M.; Kirby, M.; Lackie, P.; Sinclair, I.; et al. Small airways disease in mild and moderate chronic obstructive pulmonary disease: A cross-sectional study. Lancet Respir. Med. 2018, 6, 591-602. [CrossRef] 